\title{
Edukacja międzykulturowa w procesie wspierania rozwoju tożsamości w warunkach wielokulturowości
}

\begin{abstract}
STRESZCZENIE
Autor przedstawia działania edukacji międzykulturowej wspierające rozwój tożsamości współczesnego człowieka funkcjonującego w warunkach wielokulturowości. Analizuje trzy zakresy działalności edukacji międzykulturowej. Pierwszy, związany z akceptacją i nadawaniem znaczenia kulturze odziedziczonej. Drugi, ukierunkowany na rozwój tożsamości indywidualnej, kształtujący poczucie wolności i odpowiedzialności za rozwój własny w procesie poznawania kultury własnej i innych kultur. Trzeci, dotyczący kształtowania postaw wobec reprezentantów innych kultur, świadomości wartości uniwersalnych oraz nabywania umiejętności dialogicznych wobec licznych ofert globalnego świata.
\end{abstract}

\section{Słowa kluczowe:}

edukacja międzykulturowa, tożsamość, kultura, wielokulturowość

\section{ABSTRACT}

The author presents activities of intercultural education that support the development of the identity of a modern man functioning in the conditions of multiculturalism. He analyzes three areas of intercultural education. The first, associated with the acceptance and giving meaning to inherited culture. The second one, focused on the development of individual identity, shaping the sense of freedom and responsibility for self-development in the process of learning about one's culture and other cultures. The third is

1 Jerzy Nikitorowicz, Wydział Pedagogiki i Psychologii, Uniwersytet w Białymstoku, Polska, jerzyniki@wp.pl. 
about shaping attitudes towards representatives of other cultures, awareness of universal values and acquiring dialogic skills in the numerous offers of the global world.

\section{Keywords:}

intercultural education, identity, culture, multiculturalism

Zamierzeniem moim jest zwrócenie uwagi na znaczenie, wartość edukacji międzykulturowej w ustawicznym, niekończącym się procesie kształtowania się tożsamości współczesnego człowieka funkcjonującego w warunkach wielokulturowości. Współczesny człowiek „bezustannie pozostaje w kontaktach z obcymi (Innymi). Ponieważ zasięg jego kontaktów znacznie się zwiększył, koniecznością stało się rozszerzenie własnej kultury, a można to uczynić jedynie przez ujawnienie reguł, według których ona funkcjonuje” (Hall, 1984, s. 7). To otwarcie jest możliwe, gdy człowiek podejmuje świadomie i ustawicznie taki trud, dbając o zrównoważony rozwój (Rogalska-Marasińska, 2017). Ten trud wiążę z kategorią tożsamości, traktując tożsamość jako twórczy indywidualny wysiłek człowieka łagodzący napięcia i sprzeczności pomiędzy elementami stałymi, odziedziczonymi, które wynikają z socjalizacji i enkulturacji w rodzinie i społeczności lokalnej, identyfikacji z osobami i grupami znaczącymi, symbolami i wartościami rdzennymi a elementami zmiennymi, nabywanymi w wyniku pełnienia ról, zajmowania określonej pozycji w strukturach społecznych, realizowania potrzeb, planów życiowych w kontekście wielorakich uwarunkowań społeczno-politycznych oraz w kontekście relacji z Innymi w mezo i makrostrukturach, z doświadczeń i przeżyć w komunikacji z reprezentantami innych kultur. Twórczy wysiłek rozumiem jako siłę woli poznania swojej kultury, podstawy niezbędnej do zauważania, poznawania i uznawania innych kultur, jako ustawiczne stawanie się i otwieranie na Innych z jednoczesnym wzbogacaniem siebie i odziedziczonej kultury.

Moim zdaniem działalność edukacji międzykulturowej w tym procesie uwydatnia się wyraźnie w trzech zakresach. Pierwszy to zapoznawanie z wartościami, zasadami, symbolami kultury rdzennej, uczenie i nadawanie znaczenia kulturze odziedziczonej. Drugi to nabywanie kompetencji indywidualnych, poczucia wolności i odpowiedzialności w kontekście realizowanych ról społecznych. Trzeci zaś dotyczy postaw wobec Innych i ich kultur, umiejętności dokonywania wyborów wobec licznych ofert innych kultur. W procesie rozwoju człowieka trudno wyobrazić sobie sytuacje niemożności wychodzenia na granice swojej 
kultury, przekraczania jej, poznawania i korzystania z wartości innych kultur, wzbogacania się nimi w kształtowanych przestrzeniach życia i realizowanych rolach społecznych. Właśnie w tym procesie zauważam istotę edukacji międzykulturowej, która uznając wartość odziedziczonej kultury, nie pozwala zostać jej zakładnikiem. Z jednej strony niweluje stereotypowe postrzeganie Innych, funkcjonujące uprzedzenia, lęki, narosłe mity, strach i tym samym przeciwstawia się kształtowaniu kultur separatystycznych, megalomańskich, ksenofobicznych, nacjonalistycznych, ukierunkowujących ku konformacji sił, likwidacji (pożeraniu) Innego. Z drugiej zaś inicjuje procesy samorealizacji i aktywności twórczej, tak aby człowiek stawał się świadomym i odpowiedzialnym członkiem wspólnot, które tworzy i w których się realizuje (rodzinnej, familijnej, parafialnej, lokalnej, regionalnej, etnicznej, narodowej, kontynentalnej, planetarnej).

Założenie powyższe opieram na teorii pluralizmu kulturowego i konstruktywizmie, pedagogice humanistycznej i personalistycznej, na aktywności wewnętrznej podmiotu, transgresyjnym funkcjonowaniu, koncentracji na dialogu i refleksyjności. Istotą jest wychodzenie poza zachowawczy sposób bycia i życia. Uważam, że zjawisko nieutrzymywania danego naturalnie, odziedziczonego stanu kulturowego, jest wpisane w rozwój człowieka. Gdyby nie istniało, nastąpiłby zanik motywacji do przekraczania granic, a to wiązałoby się z końcem ludzkości (Kozielecki, 1987). Mając na uwadze proces tworzenia i rozwoju kultury przez człowieka uważam, że kultura separująca, zamykająca, izolująca od innych kultur nie rozwija tożsamości, blokuje jej rozwój i zamyka w jednym kodzie kulturowym. Był i jest to problem wielu grup etnicznych czy religijnych. Status społeczno-kulturowy był ustalony w momencie narodzin i nie było potrzeby zastanawiać się nad tym, kim się jest. Urodzenie w danej społeczności określało wyraźnie i nie było potrzeby i świadomości stawania się kimś innym. Zasady, wzorce, wartości, sankcje za odstępstwa od naturalnego zakorzenienia były jasno określone, przypisane kulturze urodzenia. Rodził się ktoś na przykład Tatarem, jednocześnie muzułmaninem, czuł się nim, nie mając innego wyboru i nie zgłaszając innych potrzeb w tym zakresie. Jak pisał Zygmunt Bauman „myśl o posiadaniu tożsamości nie przychodzi ludziom do głowy tak długo, póki gdzieś przynależą, póki nie mają alternatywy. Takie myśli mogą się pojawić dopiero w postaci zadania, które staje przed nami i którego nie da się odfajkować raz na zawsze; za każdym razem trzeba to robić od nowa” (Bauman, 2007, s. 14).

Nie sądzę, że „za każdym razem trzeba to robić od nowa”, gdyż od dzieciństwa identyfikujemy się ze „znaczącymi innymi” na wiele sposobów. Posiadamy więc jasny kod kulturowy, kierujemy się określonymi zasadami i wartościami i zgodnie z nimi podejmujemy i realizujemy zadania. Martin Heidegger zwrócił 
uwagę, że „wszystko co ważne i wielkie brało się zawsze stąd, iż człowiek miał ojczyznę i był zakorzeniony w tradycji” (Heidegger, 1977, s. 153). Tożsamość nie powstaje i nie kształtuje się w oderwaniu od rzeczywistości, gdyż tylko w niej ma miejsce enkulturacja i socjalizacja. Wskazywali na ten problem między innymi Peter Berger i Thomas Luckmann (Berger, Luckman, 1010, s. 194). Socjalizację traktuję jako część szeroko rozumianego procesu enkulturacji czy inaczej procesu ukulturalniania, kulturalizacji (Nikitorowicz, 2017, s. 40 i n.). Leon Dyczewski wyróżnił nawet pierwszorzędne i drugorzędne tożsamości społeczne jednostki. „Pierwszorzędne to takie, które obejmują całą osobowość jednostki, wszystkie jej sfery i całość jej życia, nadają mu sens i trwają całe życie. W ich obronie gotowa jest ona ponieść największe ofiary nawet z własnego życia. Do takich tożsamości należą przede wszystkim: tożsamość rodzinna, etniczno-narodowa i religijna" (Dyczewski, 2015, s. 11).

Pierwszym zakresem działalności edukacji międzykulturowej w procesie wspierania rozwoju tożsamości jest, jak wskazywałem wyżej, nadawanie wartości kulturze odziedziczonej, czyli kulturalizacja. Przynależność do grupy etnicznej, narodowej czy religijnej jest przypisana naturalnie i jednostka nie ma wyboru, jest skazana na funkcjonowanie w niej zgodnie z jej kanonem kulturowym, zasadami, wartościami, symbolami, zwyczajami, obyczajami itp. Problemy, które podejmuje edukacja międzykulturowa, dotyczą między innymi tego, czy i w jakim zakresie określone grupy socjalizują i ukulturalniają, jakie sankcje określają i stosują za przekraczanie norm czy chęć rezygnacji z nich, czy wyznaczają ostre, jednoznaczne granice, czy reprezentują postawy liberalne wobec odstępstw od tradycji, czy dopuszczają zmiany, modyfikacje, czy dopuszczają akulturację, uczestniczą świadomie czy nieświadomie w procesie akulturacji, czy uznają „przypisanie” kulturowe jako stałe i niezmienne?

Oprócz wymienionych problemów będących przedmiotem zainteresowań edukacji międzykulturowej istotne wydają się także zagadnienia związane z poczuciem uznania i szacunku do „przypisania” rodzinno-familijnego, religijnego, lokalnego, regionalnego, narodowego czy państwowego, niemniej istotnym jest problem identyfikacji, znajomości własnej kultury, przejawianych postaw wobec kanonu kulturowego, poczucie godności i uznania w kontekście wymienionych wyżej przynależności. W tym przypadku edukacja międzykulturowa wskazuje na wartość jednostki w kontekście jej osadzenia w mikrostrukturze, przynależności rasowej, płciowej, etnicznej, wyznaniowej, której nie wybiera, którą otrzymuje 
naturalnie. „Prawo do własnej kultury jest tak podstawowym prawem każdego narodu i każdej grupy etnicznej, jak prawo każdej jednostki do życia i rozwoju” (Dyczewski, 1996, s. 32). W kontekście powyższego istotne jest formułowanie i podejmowanie przez edukację międzykulturową następujących problemów: jak, ukazując przynależność religijną, historię i losy narodów, osiągnięcia i porażki, kształtować poczucie dumy i godności w kontekście przemian i dokonań współczesnych, czy równolegle obok tożsamości odziedziczonej powstają i realizują się inne tożsamości, czy i w jakim stopniu są zintegrowane z narodową lub są wobec niej konkurencyjne, czy ma miejsce i jak przebiega proces nakładania się na siebie kolejnych identyfikacji?

Tadeusz Paleczny zwrócił uwagę, że narody są największymi realnymi grupami kulturowymi, jednak nie istnieją już homogeniczne, jednorodne w sensie rasowym, religijnym, językowo-etnicznym społeczeństwa „kultury narodowej”. Podkreśla, że „coraz większą rolę we współczesnym świecie odgrywają heterogeniczne, niejednolite rasowo, etnicznie, językowo i religijnie społeczeństwa obywatelskie, zintegrowane według zasady solidarności państwowej” (Paleczny, 2006, s. 7). Uważam, że dzisiejsze życie Europejczyka przebiega w diasporze, stąd problem sztuki współżycia z różnicą i szacunku do wielu kultur w jednym człowieku, stąd problem akulturacji, transkulturacji, tożsamości hybrydowej, ustawicznego dialogu w tym zakresie. Ta sytuacja wymaga nabycia umiejętności obcowania na co dzień z formami życia odmiennymi od naszego i te problemy podejmuje edukacja międzykulturowa. Relacje kultur przestały być pionowe, a stały się poziome i kultury nie mogą domagać się od innych pokory, uległości czy uznania wyższości w kontekście bardziej postępowej, starszej czy większej.

W połowie lat 80. XX w. Komisja Europejska w swoim Raporcie dla Rady Europy wskazała na potrzebę realizowania edukacji wspierającej naukę języków i kultur kraju pochodzenia w perspektywie międzykulturowej, zwracając uwagę, że edukacja międzykulturowa stanowi ostateczny cel. Respektując specyfikę kulturową zmierza do przezwyciężenia izolacji nie poprzez zwiększanie różnego rodzaju informacji w treściach programowych, a poprzez stosowanie zasad, form i metod sprzyjających wzajemnemu zrozumieniu. Stąd edukacja międzykulturowa powinna objąć ogół populacji szkolnej w kilku wymiarach. „Pierwszy sprowadza się do prostej konstatacji: 10\%, 20\%, a niekiedy nawet 80\% uczniów w klasie reprezentuje inne kultury niż kraj ich pobytu, nauczyciele i uczniowie są świadomi tej różnorodności. Drugi to wzajemne zrozumienie: autochtoni i imigranci uczą się akceptacji i respektowania odmienności Innego. Trzeci, najbardziej wartościowy, to wzajemne wzbogacanie wiedzy i postaw dzięki obecności różnych kultur” (Paleczny, 2006, s. 7). W tym kontekście Komisja Europejska wskazuje na międzykulturowość 
jako ogół praktyk edukacyjnych mających na celu propagowanie szacunku i wzajemnego zrozumienia między uczniami, niezależnie od ich przynależności kulturowej, lingwistycznej, etnicznej czy religijnej. Poznając kultury uczniowie będą mogli dostrzec ich bogactwo i różnorodność, będą mogli poddać je osądowi. Nie niwelując różnic, uczniowie będą mogli je odkrywać i w efekcie orientować się w nich i dokonywać wyborów. Tak więc istotą jest uznanie obecności różnych kultur w społeczeństwie i traktowanie ich jako czynnika wzajemnego wzbogacania się, jak też konfrontacji wartości, wielokrotnie niespójnych i przeciwstawnych, stąd edukacja międzykulturowa w pierwszym rzędzie ma uczyć mediacji i rozwiązywania konfliktów. Jak wskazują Edyta Januszewska i Urszula Markowska-Manista istotne jest „otwarcie międzykulturowe”, które zakłada poszukiwanie nowych strategii, rozwiązań i sposobów na pracę edukacyjną w heterogenicznej kulturowo szkole. Autorki zwracają uwagę, że głównym celem procesów międzykulturowego otwarcia jest zagwarantowanie sprawiedliwego dostępu do obszarów usług dla członków przynależnych do mniejszości narodowych, etnicznych, uchodźców, migrantów, a także przeciwdziałanie mechanizmom ich wykluczania. Celem jest integracja społeczna i włączenie mniejszości w codzienne życie społeczeństwa większościowego (Januszewska, Markowska-Manista, 2017, s. 12-13).

Podsumowując powyższe uważam, że zadaniem edukacji międzykulturowej w pierwszym zakresie wspierania rozwoju tożsamości jest kształtowanie świadomości, że nie mamy raz na zawsze danej tożsamości, że mamy wiele możliwości identyfikacyjnych, że obowiązkiem współczesnego człowieka jest konieczność zauważania Innego, potrzeba wychodzenia na pogranicza kultur, ich przekraczania, aby je poznawać i wzbogacać się różnicami. Edukacja międzykulturowa nie pozwala więc na zamknięcie tożsamościowe, ukazuje możliwości, rozbudowuje identyfikacje, ukazuje ich mnogość, buduje wspólnoty, kształtuje więzi. Stąd ważne jest wdrażanie w tym procesie do odpowiedzialnych i wartościowych wyborów, tworzenie rozwojowych relacji, nabywanie kompetencji do funkcjonowania w wielokulturowym świecie. W kontekście powyższego edukacja międzykulturowa podejmuje trud wyzwalania człowieka z biologicznego trwania w lęku, uczy szacunku do własnej kultury i innych kultur, wzmacnia rdzenne, odziedziczone wartości, co pozwala świadomie i odpowiedzialne wychodzić poza kulturę przejmowaną nieświadomie. Inaczej mówiąc, edukacja międzykulturowa wprowadza człowieka w ciągły proces konstruowania siebie z jednoczesnym uwrażliwianiem na Innych, ich potrzeby związane z kultywowaniem własnych wartości, zasad i norm kulturowych. Poza tym podejmuje działania przeciwstawiające się ideologizacji własnego narodu, kierując się między innymi następującym wskazaniem. „Ideologizacja własnego narodu jest przejściem od uznawania go za podstawową wartość 
społeczną i kulturową do wyniesienia go do najwyższej wartości, przypisania mu doskonałości i wyższości, przekonania o własnym wybraństwie i misji w stosunku do innych grup etnicznych. Przybiera to formy etnocentryzmu, megalomanii, nacjonalizmu, ksenofobii i szowinizmu. Naród osiągnąwszy najwyższą wartość społeczną i kulturową w świadomości swoich członków, urasta także do najwyższej wartości politycznej. Domaga się wówczas wzmocnienia swojej pozycji w ramach państwa, w jakim istnieje i wśród innych narodów. Najczęściej towarzyszy temu manichejskie dzielenie grup etnicznych i narodów na dobre i złe, na rozwinięte i nierozwinięte, na przyjacielskie i wrogie” (Dyczewski, 1993, s. 24).

W drugim zakresie działalność edukacji międzykulturowej wspierającej rozwój tożsamości skupia się na kształtowaniu kompetencji indywidualnych wyzwalających z naturalnego wpisania kulturowego, ale bazującej na nim, z jednoczesnym korzystaniem z innej oferty wyborów identyfikacyjnych. W tym przypadku chciałbym zwrócić uwagę na dwukierunkowość edukacji międzykulturowej, interaktywność dialogu w kontekście różnorodności grup kulturowych. W ujęciu symbolicznego interakcjonizmu jednostka kształtuje swoją tożsamość poprzez odniesienia do grupy, której jest członkiem. G. Mead wskazywał na tożsamość jako sprzężenie dwóch postaci Ja: Ja interakcyjnego - przedmiotowego oraz Ja podmiotowego - subiektywnego. Te postacie Ja wykształcają się w procesie dialogu - zewnętrznego i wewnętrznego. Jak ważny jest to problem, jakie znaczenie ma dialog dla rozwoju tożsamości człowieka możemy zauważyć w myśli hermeneutycznej i w socjologii rozumiejącej, gdzie zwraca się uwagę nie na posiadanie, osiągnięcie stanu, a na proces. Człowiek naturalnie „zanurzony” w kulturze rodzimej dziedziczy nieświadomie, co jednak decyduje o sposobach odczytywania świata, wyborze treści, ich poszukiwaniu, interpretacji, nadawaniu znaczenia, zrozumieniu itp. Rozumienie i zrozumienie wydaje się być istotne dla hermeneutyki, a osiąganie tego odbywa się poprzez dialog, co warunkuje ludzkie bycie w świecie (Gadamer, 2004, s. 413 i n.).

\section{Edukacja międzykulturowa, uwzględniając perspektywę interakcjonizmu} przyjmuje, że posiadając ciekawość poznawczą, będziemy wchodzili w interakcje i wzbogacali się wzajemnie. W zależności od warunków i sytuacji będą kształtowany się poglądy i przekonania, obraz Innych, w zależności od odbioru siebie i oczekiwań wobec siebie będą powstawały określone postawy i będzie wyrażany sąd o Innych. W każdym razie będzie powstawał i coraz wyraźniej precyzował się własny obraz, będzie się kształtowała samoocena, liczba i poziom identyfikacji, 
postawy wobec swoich i innych. Jak podkreśla M. Budyta-Budzyńska „refleksję grupy o sobie samej tworzą wyobrażenia na temat wizerunku grupy wśród innych, o którym członkowie grupy wnioskują na podstawie przesłanek pośrednich zachowań i postaw innych wobec niej” (Budyta-Budzyńska, 2010, s. 96). Tak więc w kontekście interakcjonizmu konstruowanie tożsamości człowieka odbywa się w interakcjach, które pozwalają siebie poznać, zauważyć i zrozumieć różnice między grupami, zrozumieć i współpracować z sobą. Może także powstawać i rozwijać się opozycja my-oni, swoi-inni. Właśnie tu zauważam potrzebę wkraczania edukacji międzykulturowej, gdyż kształtowanie się tożsamości jest kształtowaniem biegu życia ludzkiego (Buchner, 1999), ustawicznym błądzeniem, przeżywaniem dylematów związanych z bezpiecznymi wyborami. Ks. Adam Boniecki zwrócił uwagę, że: „Historia naszego wnętrza jest historią naszej wolności. A wolność jest przestrzenią. Pustynią. Rodzi się tam także pokusa, zawsze ta sama, co w opowieści z księgi Genesis: by samemu decydować, co jest dobrem, a co złem” (Boniecki, s. 13). Podkreślił: „Panowanie i służba, egoizm i altruizm, posiadanie i dar, interesowność i bezinteresowność: te głęboko sprzeczne logiki ścierają się ze sobą w każdym czasie i w każdym miejscu” (Boniecki, s. 20-21).

Edukacja międzykulturowa przygotowuje do dialogu zewnętrznego i wewnętrznego, do relacji opierającej się na zasadach równorzędności i dobrowolności. Celem dialogu wewnętrznego i zewnętrznego jest wzajemne zrozumienie, celem zaś tego zrozumienia konieczność wzajemnego zbliżenia, a to zrozumienie i zbliżenie osiąga się na drodze poznania siebie i Innych. Jak pisze Tadeusz Paleczny „Dialog międzykulturowy jest traktowany w koncepcjach teoretycznych i w projektach politycznych wielokulturowości jako warunek konieczny istnienia i funkcjonowania złożonych społeczeństw obywatelskich. Bez tej formy komunikacji nie da się kształtować i utrzymywać jakiejkolwiek właściwej dla zrównoważonego, zintegrowanego społeczeństwa struktury pluralistycznej” (Paleczny, 2017, s. 187-188). Zwraca uwagę, że dialog jest następstwem kontaktu i doświadczania wielokulturowości, staje się obszarem wspólnych wartości, kształtowania i utrwalania przestrzeni międzykulturowej. Zachodzi nie tyle pomiędzy kulturami, a pomiędzy ludźmi, przybierając formę negocjacji prowadzących do ustalenia wspólnego stanowiska i przyjęcia kompromisu (Paleczny, 2017, s. 188-189).

W kontekście powyższego wyzwaniem i zadaniem edukacji międzykulturowej jest więc heterologia, nauka o Innym, odmiennym, różniącym się, niejednorodnym, jak też wielokulturowym, hybrydowym. Zakłada uczestnictwo w kulturze własnej i prowadzenie ustawicznego dialogu z Innym w kontekście odpowiedzialności za kreowanie pokoju, poczucia współuczestnictwa w tym procesie. Wzajemne uznanie i wyrażanie szacunku kreuje wzory komunikacji 
społecznej, poprzez które dokonuje się wielokierunkowy transfer treści kultury, zasad, wzorów i wartości. Edukacja międzykulturowa promuje heterologię jako ideę, zasadę i postawę przejawiającą się w poglądach wielu filozofów i pedagogów dialogu. Przedstawiciele tego nurtu polem swoich zainteresowań objęli przede wszystkim człowieka w relacji z „Innym”, z drugim człowiekiem, podkreślając, że każdy człowiek stanowi wartość samą w sobie. Dla filozofii dialogu wartościowymi aspektami jest dostrzeganie, szacunek i szczera chęć zrozumienia drugiego człowieka i odpowiedzialność za „Innego”, co należy traktować w kategorii nakazu etycznego. Ks. Józef Tischner pisał, że człowiek prowadzi „grę o odpowiedzialność” (Tischner, 1995, s. 47) i albo przyjmuje ją, albo odrzuca. Powołując się na tezę Emmanuela Lévinasa (Lévinas, 1994) wskazywał, że odpowiedzialność żyje w stanie uśpienia w każdym z nas, a wyzwolić ją może próba nawiązania kontaktu, wejście w interakcje. Człowiek może też wybrać drogę ucieczki od odpowiedzialności, będzie to jednak ucieczka od ludzi, od relacji dialogu, od pytań, od odpowiedzi, czyli niemożliwość wejścia w proces gromadzenia treści z różnych kultur, ich łączenia i przyswajania, zapożyczeń itp. Człowiek odpowiedzialny wybiera świadomie i dobrowolnie określoną drogę życiową, a pragnąc ją wzbogacić, zmierza ku otwartej przestrzeni dialogicznej, opartej na realizowaniu wartości wzbogacających go. „...Człowiek służy wartościom - realizując je, wartości służą człowiekowi - ocalając go...” (Gadacz, 2004, s. 80).

Wiodącą wartością jest nabycie kompetencji do funkcjonowania w wielokulturowym świecie. Heterologię łączę z paradygmatem kulturowo-antropologicznym (zróżnicowanie jest produktem naturalnego rozwoju historycznego w określonej przestrzeni geopolitycznej, a odmienne wspólnoty kulturowe można poznać, zrozumieć, wyjaśnić). Poczucie odrębności, spójności, charakter odmienności i kierowanie się określoną ideologią jest wynikiem czynników społecznych, posiadania własnego terytorium, odrębności ekonomicznej itp. To decyduje o stopniu podporządkowania lub dominacji w stosunku do innych grup. Heterologia określa zasady życia społecznego, kształtuje postawy otwarte, niweluje etnocentryzm i socjocentryzm, negatywne wyobrażenia Innych. Można powiedzieć, że przyczynia się do kształtowania postaw poczucia wspólnoty gatunku ludzkiego ponad różnicami, które są niezbędne do rozwoju ludzkości w kontekście humanistycznego paradygmatu pokojowego rozwoju i współistnienia.

Uważam, że edukacja międzykulturowa winna podejmować działania związane z rewitalizacją heterologii, aby uczyć o wielości kultur w jednym człowieku, czyli przynależności do wielu kultur jednocześnie. Jej istotą jest organizowanie warunków i stwarzanie sytuacji do nabywania świadomości postrzegania człowieka 
z wielością kultur, które wzbogacają jednocześnie Innych. Rewitalizacja związana jest także z kształtowaniem wrażliwości postrzegania i analizy innych kultur, zauważaniem ich złożoności i wielowymiarowości, świadomości odrębności kultur bliższych i dalszych cywilizacyjnie, bardziej i mniej zrozumiałych kultur, których zasad i wartości nie jesteśmy w stanie zaakceptować, nieprzystawalnych i niezrozumiałych, nie tylko w kontekście prawnym, ale także humanistycznym, w kontekście powszechnie uznawanych wartości uniwersalnych.

$*$

Trzeci zakres działań edukacji międzykulturowej wspierających rozwój tożsamości skupia się na kształtowaniu postaw i umiejętności dotyczących korzystania z różnych ofert innych kultur, tym samym uczestniczenia w procesie kształtowania społeczeństwa wielokulturowego. Edukacja międzykulturowa traktuje wielokulturowość jako wartość edukacyjną, a interakcje z Innymi jako niezbędny element własnego rozwoju i kultury oraz możliwość kształtowania tożsamości otwartej, wielozakresowej i wielowarstwowej. Prowadzona przez nas działalność edukacyjna nie narzuca idei wielokulturowości jako politycznie poprawnego punktu widzenia, a analizuje naturalne, wielowiekowe pogranicza kultur, ukazuje ludzi pogranicza, złożoność kreowania ich tożsamości, trudne wybory, podejmuje próby niwelowania uprzedzeń i stereotypów, funkcjonujących i podtrzymywanych mitów edukacyjnych. Staramy się z jednej strony dostrzegać i eksponować tzw. „dobrą pamięć”, pozytywne strony, doznania i wartości, z drugiej zaś wskazywać i analizować w kontekście „współczynnika humanistycznego” Floriana Znanieckiego „złą pamięć”, negatywne nastawienia, krzywdy i upokorzenia mające miejsce na pograniczu kultur. Nie kreujemy jednostronnego obrazu wielokulturowej przeszłości jako stanu harmonii, a próbujemy poszukiwać źródeł napięć i konfliktów, skutków dominacji politycznej i kulturowej jednej kultury nad drugą. Analizujemy w różnych ujęciach i kontekstach terytorialne pogranicze stykowe i przejściowe, treściowe, interakcyjne i świadomościowe.

Edukacja międzykulturowa odwołuje się więc między innymi do propozycji Ulricha Becka, do oferty nowego popkosmopolityzmu, swoistej eklektyzacji kulturowej, przynależenia do wielu kultur naraz, co może chronić nowe kultury przed ortodoksją. Pisze On: „Kosmopolityzm uznaje, że Europejczycy mają dziś wiele różnych nakładających się tożsamości. Tożsamość narodowa, tak jak rozumiano ją w XIX w. staje się iluzją, nawet jeśli nacjonaliści nie chcą tego przyjąć do wiadomości, że Turcy w Niemczech nie są Turkami z Turcji, Polacy w Anglii nie będą tacy jak w Polsce” (Beck, 2007). 
Obywatele poszczególnych krajów różnią się, chcą się różnić i coraz częściej upominają się o prawo do redefinicji swoich tożsamości osobowych i kulturowych. Sądzę, że ta wewnętrzna różnorodność, jak wskazuje W. Welsch, stanowi trwały potencjał, do którego prędzej czy później, przy takiej okazji czy innej, można powracać, aby od nowa tworzyć wielość opcji, objawiających prawdziwie transkulturowy charakter pozornie narodowych kultur (Welsch, 2004, s. 34).

Uważam, że zjawisko każdej hybrydy powoduje z jednej strony rozluźnianie ścisłego związku między państwem i narodem a obywatelstwem. Problem separacji tożsamości obywatelskich od narodowych w kontekście globalizacji wydaje się nabierać szybkości. Idea obywatelstwa postnarowodowego wymuszana jest przez migracje, ale i świadome wielokulturowe i międzykulturowe działania rządów, kościołów, ruchów obywatelskich. Obywatelstwo jakby uwalnia od nacisku i zawłaszczenia tożsamościowego (Habermas, 2005, s. 548-571; Bauman, 2006, s. 286-297). Z drugiej strony chciałbym zauważyć, że w dzisiejszym, wielokulturowym świecie mamy do czynienia z wieloma globalnymi praktykami kulturowymi obok specyficznych praktyk narodowych. Jak stwierdza Zbyszko Melosik, jedną z najbardziej istotnych praktyk kulturowych, w kontekście innych, rozproszonych i niekiedy sprzecznych ze sobą (muzyka, moda), jest piłka nożna: „... trwa w swojej integracji, w swoim wariancie niemalże klasycznym. Jest skonsolidowana wokół swoich reguł i rozgrywek oraz przekazywanych z pokolenia na pokolenie indywidualnych, rodzinnych i kolektywnych identyfikacji” (Melosik, 2016, s. 179). Zwraca uwagę, że ze względu na swoją atrakcyjność i źródło identyfikacji nabrała bezklasowego charakteru, stając się istotnym elementem kultury kształtującej tożsamość narodową.

Sądzę, że w tym zakresie edukacja międzykulturowa podejmuje trud działań profilaktycznych, aby wdrożyć obywateli do panowania nad emocjami, aby w społeczeństwie nie powstały i nie wzięły górę namiętności, aby człowiek mógł przystąpić i zdać egzamin z człowieczeństwa. Przecież w okresie poprzedzającym I wojnę światową nikt nie przypuszczał, by Europejczycy, poważni przedstawiciele religii, nauki, ustalonego porządku, mieli nagle strzelać do siebie, popełniać niezliczone okrucieństwa. Do dnia dzisiejszego nie jesteśmy w stanie zrozumieć i rozliczyć się z tamtą przeszłością. Ludwik Hirszfeld, przedstawiając historię swojego życia, pisał: „Z otchłani zaczęły się wyłaniać jakieś potwory nienawiści, okrucieństwa i głupoty i obejmować duszę ludzką śliskimi palcami. Z człowieka, który był dumny, że osiągnął szczyt cywilizacji, uczyniono twór gorszy od zwierzęcia, twór, który odwrócił historię świata i cofnął ją o kilka tysięcy lat. Umysł ludzki zdał egzamin tylko jako twórca narzędzi zbrodni. Jako realizator etyki współżycia człowiek okazał się niższy od troglodytów. Spotkałem po wojnie 
Murzyna, który wracał do Afryki. Mówił, że wraca, gdyż nie może znieść dzikości Europy. W Afryce przynajmniej zjadają, gdy zabijają; tu zabijają dla przyjemności” (Hirszfeld, 2011, s. 48).

Dlaczego tak funkcjonował i funkcjonuje człowiek, jak to zrozumieć i wyjaśnić epistemologiczne? Jak wskazuje Marek Nowakowski, analizując wydarzenia związane z marcem '68, w społeczeństwie górę wzięły namiętności i zaczęły dominować zachowania haniebne nad szlachetnymi, małość nad wielkością człowieka. Zaczęło się rozliczanie, wskazywanie, kto jest syjonistą, następnie prześladowanie, atakowanie i pozbawianie obywatelskości na zawsze (Nowakowski, 2009).

Stąd edukacja międzykulturowa podejmuje powyższe problemy, aby tożsamość hybrydowa nie powodowała doświadczania wyobcowania i izolacji. Odwołuje się do znaczących postaci, takich np. jak Janusz Korczak, który wierząc w przyjaźń i pokój między narodami, wyznaniami i rasami, czując się jednocześnie Żydem i Polakiem, doświadczał wykluczania ze wspólnoty narodowej przez rasizm endecki, któremu między innymi przeciwstawiał się także Czesław Miłosz. Formułujemy i podejmujemy odpowiedzi - jak chlubić się Polakiem żydowskiego pochodzenia, czując się Polakiem i Żydem równocześnie? Tak bowiem myślał sam o sobie Korczak, zawsze podkreślając podwójną tożsamość. Należy zauważyć dumę i jednocześnie zakłopotanie Polski z Korczaka, także Ludwika Zamenhoffa. Sądzę, że z biografii tych i wielu innych osób możemy się uczyć, jak być jednocześnie Żydem i Polakiem, Ukraińcem i Polakiem, Niemcem i Polakiem itd. Korczak urodzony w polonizującej się żydowskiej rodzinie Goldszmitów myślał i pisał po polsku, podpisywał się pseudonimem - Korczak, ale nie wyrzekał się swojej żydowskości i cenił ją. Żydowskie dzieci w Domu Sierot wychowywane były w duchu podwójnej tożsamości - uczyły się języka polskiego i żydowskiego, historii, kultury, tradycji obu narodów, tolerancji do odrębności, poczucia, że Polska jest Ojczyzną. Za takie myślenie podwojone nie lubili go „prawdziwi Polacy”, ani syjoniści, ani Żydzi ortodoksyjni, ani asymilatorzy. Czy nie trwa to zjawisko do dnia dzisiejszego, dlaczego tak trudno żyć, być sobą, gdy nie mieścimy się w żadnych ideologicznych schematach?

W kontekście powyższego edukacja międzykulturowa ustawicznie podejmuje próby odpowiedzi na pytania: jak zauważać i szanować wielość kultur w jednym człowieku, czy eklektyzm w tym zakresie jest możliwy, z jakimi dylematami tożsamościowymi muszą uporać się ludzie pogranicza kultur?

To, co jest istotą edukacji międzykulturowej, jak starałem się wskazać wyżej, to wskazywanie możliwości rozwojowych w komunikacji z Innymi nie tylko na pograniczach kulturowych, ale na możliwości interakcji i nabywania umiejętności funkcjonowania na pograniczach świadomościowych jako efekt symetrycznego 
poznawania się, zrozumienia złożoności i wielowarstwowości tożsamości. W tym zakresie edukacja międzykulturowa bada i kształtuje relacje między kulturami wskazując na znaczenie wartości i zasad uniwersalnych, humanistycznych (Nikitorowicz, 2017, s. 48-73). Jak wskazuje Marek Rembierz, edukacja międzykulturowa staje przed trudnym zadaniem kształtowania postaw sprzyjających zawiązywaniu i rozwijaniu relacji międzykulturowych. W tym kontekście troska o kulturę intelektualną wydaje się stanowić jeden z podstawowych wymiarów rozwijania teorii i praktyki edukacji międzykulturowej (Rembierz, 2017, s. 37-67).

\section{Bibliografia}

Bauman, Z. (2007). Tożsamość. Rozmowy z Benedetto Vecchim. Tłum. Jacek Łaszcz, Gdańsk: GWP.

Beck, U. (2007). Unia nie jest tylko dla elit. Gazeta Wyborcza, 22 czerwca.

Berger, P., Luckmann, T. (2010). Społeczne tworzenie rzeczywistości. Traktat z socjologii wiedzy. Warszawa: Wydawnictwo Naukowe PWN.

Boniecki, A. (2017). Powroty z bezdroży. Notatki na marginesach Biblii, Kraków: wyd. WAM.

Buchner, Ch. (1999). Bieg życia ludzkiego. Warszawa: Wydawnictwo Naukowe.

Budyta-Budzyńska, M. (2010). Socjologia narodu i konfliktów etnicznych, Warszawa: Wydawnictwo Naukowe.

Dyczewski, L. (2015). Tożsamość religijna. W: L. Dyczewski, K. Jurek (red.), Tożsamość religijna w nowoczesności, Lublin: Wydawnictwo KUL.

Dyczewski, L. (1996). Naród podmiotem kultury. W: L. Dyczewski (red.), Tożsamość polska i otwartość na inne społeczeństwa, Lublin: Wydawnictwo KUL.

Dyczewski, L. (1993). Trwałość kultury polskiej. W: L. Dyczewski (red.), Wartości w kulturze polskiej. Lublin.

Gadacz, T. (2004). Chrześcijańskie korzenie Tischnerowskiej filozofii człowieka. Znak, 5. Gadamer, H.G. (2004). Prawda i metoda. Warszawa: PIW.

Habermas, J. (2005). Faktyczność i obowiq̨zywanie. Teoria dyskursu wobec zagadnień prawa i demokratycznego państwa prawnego. Tłum. A. Romaniuk, R. Marszałek. Warszawa: Scholar.

Hall, E.T. (1984). Poza kulturq. Tłum. E. Goździak, Warszawa: Wydawnictwo Naukowe PWN.

Heidegger, M. (1977). Tylko Bóg mógłby nas uratować. Tłum. M. Łukaszewicz. Teksty 3 (33).

Hirszfeld, L. (2011). Historia jednego życia. Warszawa: Wydawnictwo Literackie.

Januszewska, E., Markowska-Manista, U. (2017). Dziecko „Inne” kulturowo w Polsce. $Z$ badań nad edukacjq szkolnq. Warszawa: Wyd. APS.

Kozielecki, J. (1987). Koncepcja transgresyjna człowieka. Warszawa: Wydawnictwo Naukowe PWN.

Lévinas, E. (1994). O Bogu, który nawiedza myśl. Kraków: Wydawnictwo Znak. 
Melosik, Z. (2016). Piłka nożna. Tożsamość, kultura i władza. Poznań: Wydawnictwo Naukowe UAM.

Nikitorowicz, J. (2017). Etnopedagogika w kontekście wielokulturowości i ustawicznie kształtujq̨cej się tożsamości. Kraków: Impuls.

Nikitorowicz, J. (2017). Nowe wyzwania edukacji międzykulturowej wobec zmian w polityce wielokulturowości. W: Edukacja międzykulturowa jako czynnik rozwoju kultury pokoju. Gdańsk: Wyd. Naukowe „Katedra”.

Nowakowski, M. (2009). Syjoniści do Syjamu. Zapiski z lat 1967-1968. Warszawa: Wydawnictwo „Świat Książki”.

Paleczny, T. (2006). W poszukiwaniu nowych perspektyw badań i studiów nad wielokulturowościq. W: K. Golemo, T. Paleczny, E. Wiącek (red.), Wzory wielokulturowości we wspótczesnym świecie. Kraków: Wyd. Uniwersytetu Jagiellońskiego.

Paleczny, T. (2017). Relacje międzykulturowe w dobie kryzysu ideologii i polityki wielokulturowości. Kraków: Księgarnia Akademicka.

Rembierz, M. (2017). Kultura intelektualna, wątpliwości metodologiczne i refleksja metapedagogiczna w rozwijaniu teorii i praktyki edukacji międzykulturowej. Edukacja Międzykulturowa, 2 (7).

Rogalska-Marasińska, A. (2017). Edukacja międzykulturowa na rzecz zrównoważonego rozwoju. Łódź: Wydawnictwo Uniwersytetu Łódzkiego.

Tischner, J. (1995). Gra wokół odpowiedzialności. Znak, 10.

Welsch, W. (2004). Narodziny filozofii postmodernistycznej z ducha sztuki modernistycznej. W: R. Nycz (red.), Odkrywanie modernizmu. Kraków: Universitas. 